\title{
Influences of Modern Calculation Tools and Efficiency of Insurance Management in the Global Pandemic Period
}

\author{
Ikboljon Odashev Mashrabjonovich \\ Editorial and Publishing Department, Institute of Forecasting and Macroeconomic Research under the Ministry of Economic \\ Development and Poverty Reduction of the Republic of Uzbekistan, Tashkent, Uzbekistan \\ Email: Iqboljon.Odashev@gmail.com,Iqbol.Odashev@mail.ru
}

How to cite this paper: Mashrabjonovich, I. O. (2021). Influences of Modern Calculation Tools and Efficiency of Insurance Management in the Global Pandemic Period. Modern Economy, 12, 495-515. https://doi.org/10.4236/me.2021.123026

Received: November 23, 2020

Accepted: March 15, 2021

Published: March 18, 2021

Copyright (๑) 2021 by author(s) and Scientific Research Publishing Inc. This work is licensed under the Creative Commons Attribution International License (CC BY 4.0).

http://creativecommons.org/licenses/by/4.0/ (c) (i) Open Access

\begin{abstract}
Object: The main purpose of the research is to develop modern tools for the insurance management in the global economic crisis, to make an objective assessment based on a critical analysis of existing ones, to identify situations that could lead to international economic, social and natural threats. It is made some recommendations for the development of insurance calculations for the republic of Uzbekistan. Methods: Methods for reforming modern calculation of insurance tariffication are recommended by means of theories of probabilities, statistical and mathematical analysis, and foreign advanced countries practical types of summarizing. Findings: While making an analysis, it has found that modern tools for the insurance management of Uzbekistan are needed. We proved this by the results of modern calculation of insurance. For the development of insurance market of Uzbekistan, it should be analyzed by means of penetration and density of insurance premiums, making the deepest calculation of risks of the economy of Uzbekistan, and using the main principals and formulas of theory of probability. Conclusions: In the end, we can take some results, and give some recommendations such as using the tools of theories of probabilities can help us find the main risks of economy, it's powers of influences of the market economy, statistical and mathematical analysis also add some practical, objective results for making under control of any types of insurance risks.
\end{abstract}

\section{Keywords}

Insurance Market, Risks, Modern Criteria, Global Risks, Financial Risks, Insurance Reserves, Losses, Insurance Premiums, Penetration, Premium Density, Modern Calculation, Compulsory, The Theory of Probability, Insurance Management, Insurance Development 


\section{Introduction}

Unexpectable dramatic changes in the world economy, lack interconnectedness, and a unified solution to protect all the mechanisms of the market economy from various threats, varieties of natural disasters, epidemics which threaten humanity, anticipate its impact on the world economy, and so on. It poses important issues that need to be addressed by insurance companies to be prepared. For example, according to Bloomberg, the spread of the new strain of COVID-19 coronavirus pandemic is causing the global economy to lose up to $10 \%^{1}$ of its gross domestic product, and its annual growth rate to zero or less in almost all countries. The fact that the total amount of losses is equal to the annual GDP of some countries with strong economies indicates that the problem is serious. "The Covid-19 pandemic has hit the global economy, leading to a global recession. The decline in the economies of the SCO (The Shanghai cooperation organization) member states this year will amount to $3.2 \%$, which is less than in the rest of the world. The projected fall in the global economy for the year is estimated at $4.4 \%^{20}$, said the President of the Republic of Russian Federation, Vladimir Vladimirovich Putin. Accurately assessing the impact of similar global events on future financial relationships, calculating potential global risks, and organizing insurance product offerings accordingly requires current insurance company executives to define new criteria for effective business management.

\section{Materials and Methods}

All sectors of the market economy cover a variety of economic processes, which are carried out based on generally accepted rules of the market economy.

These include supply and demand, market equilibrium, competition, labour relations, the formation of macro-, micro- and national economies, the emergence of consumption and savings and investment activities, economic cycles, the importance of the monetary and banking system, the relationship between the state and market economy participants. The logical outcome of these processes can be categorized based on the following groups of economic laws:

1) General economic laws-apply at all stages of the development of human society. For example, the law of saving time, the law of rapid growth of needs, the law of reproduction, the law of conformity of the nature and level of development of the productive forces of production relations, and so on.

2) Private or periodic economic laws-apply at certain stages of the development of human society. For example, the law of supply and demand, the law of value.

3) Special economic laws-apply in the context of a separate economic system. For example, the law of value-added.

One of the common features of these processes that take place in a market economy is that events involving risk, or probability, and the economic condi-

${ }^{1}$ https://www.dw.com/ru (Conclusion of the experts of the Asian Development Bank).

${ }^{2}$ The videoconference of the Council of Heads of State of the Shanghai Cooperation Organization. 10.11.2020. 
tions that characterize their consequences, are inextricably linked.

For example, the risks associated with the timely repayment of loans provided by the bank (bankruptcy of the borrower, falling solvency, rising inflation, etc.), the risks of the proposed finished goods and services less than planned, or consumers of manufactured goods the risks associated with the rapid growth and decline of needs, the risks associated with the return of foreign investment, the risks associated with the rapid volatility of incomes, the many economic risks associated with competition in the domestic market due to economic integration of various world economies. These risks are represented as a daily, frequent, and typical economic situation among market economy participants. All entrepreneurs, business people, and business participants who face these types of risks have a variety of solutions, methods, formed based on their practical experience, knowledge, and skills.

There are also risks in the economy, which offer the possibility of protection against future accidents with the participation of representatives of certain sectors, in other words, insurance.

Insurance activity is an integral part of financial and economic relations in a market economy which is understood to protect their interests through payment ${ }^{3}$.

Insurance companies insure against risks that their participants do not want to lose in the future in a market economy and help reduce the number of financial errors by making the appropriate amount of insurance payments under the contract in the event of an insured event.

In this regard, the implementation of measures to improve the efficiency of insurance management requires the management of insurance companies to develop new management criteria, to effectively assess the current global risks, its scope, future insurance risks, and financial risks.

The Global Threats 2020 Report which dedicated to the World Economic Forum, identifies economic, environmental, geopolitical, social, and technological types of threats facing the world today. By this report results we can conclude following (Swiss Resigma, 2020):

In general, in the context of global economic and financial risks, the question arises as to which categories of economic entities are prone to insurance. From a logical sequence, we can say that we can get an answer by assessing how much they need insurance by giving the following to the affected sectors arising from the global economic, financial and socio-political situation.

1) World financial markets (stock exchanges, brokers, etc.);

2) Large international enterprises and organizations (Apple, Microsoft, Huawei, etc.);

3) International social and cultural facilities (entertainment venues, parks, sports fields, etc.);

4) International economic and financial relations (diplomatic relations, issues related to international trade in goods and services, etc.);

${ }^{3}$ Source: The Law of the Republic of Uzbekistan “On insurance activity” (05.04.2002 N 358-II). 
5) Problems related to international tourism, international migration;

6) Financial crises in the regional economy and its impact on the world economy;

7) The risk of delay or loss of international investors and their expected return on investment activities.

To be able to identify and prevent other similar negative developments in the infrastructure of a market economy, to accurately assess the level of mobilization of insurance activities to reduce the expected losses, to develop a clear strategy to overcome the global economic crisis with minimal losses and implement it promptly, the development and offering of touch insurance products for the affected sectors arising from the global economic-financial and socio-political situations listed above is one of the current issues. Based on this, we will identify the real situations for the above and assess the need for effective participation of insurance activities in it one by one. As research methods, we evaluate using several computational tools such as comparative analysis, the density of insurance premiums in the economy, SWOT-analysis, mathematical expectation, and normal distribution of losses, which help to determine the place of insurance activity in the world economy.

Like other markets, the insurance market differs from one another in both developed and developing countries. Here, the density of insurance and the share of insurance in the economy are different, and the density of insurance is the degree of insurance, defined as the ratio of total insurance premiums for a year per capita in the selected country in monetary terms or percentages. The share of insurance in the economy is calculated as the ratio of the total calculated insurance premiums to the gross domestic product for a year in the selected country.

In a market economy, the demand for insurance depends on the size of the property of consumers and their income. For example, in developed countries, a certain consumer, on the one hand, feels the need to ensure his assets to protect

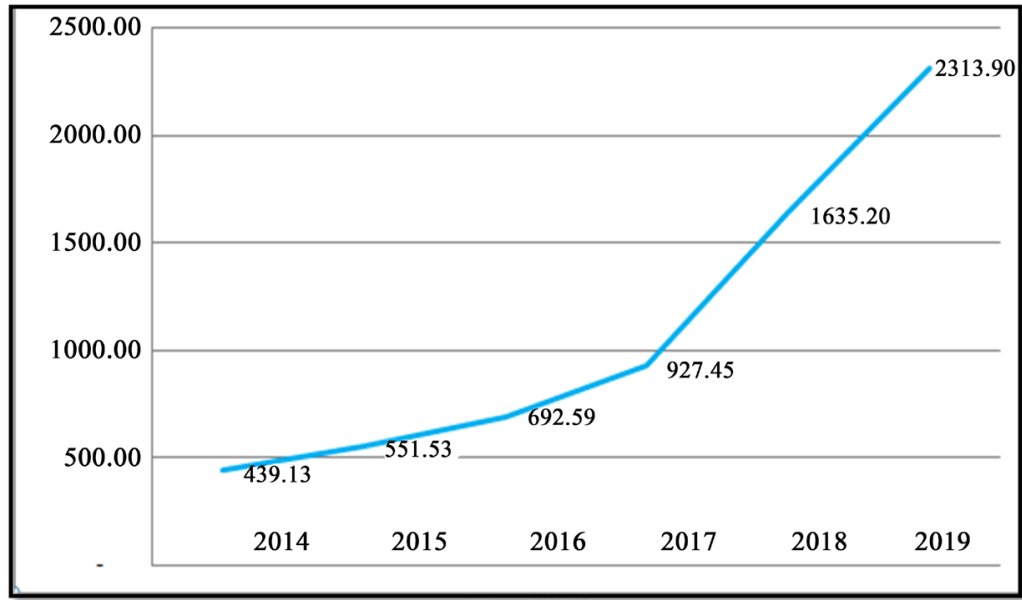

Source: Data from the author.

Figure 1. The volume of insurance premiums accrued in the country (mlnUZS). 
against future market economy risks, and on the other hand, to further increase the income from their activities, can ensure the health of loved ones. According to economists, insurance companies believe that it will increase the country's productive capacity, as well as make a significant contribution to improving the living conditions of society and increasing the level of welfare. This means that as consumers' wealth and income increase, so do their insurance needs. This will ensure that various enterprises and organizations, business entities, businessmen, foreign firms, and companies in the country will be able to carry out their economic and financial activities independently and without risks.

Among the Central Asian countries, the Republic of Uzbekistan also has insurance companies, which are one of the most important participants in the market economy. As of December 31, 2019, there are a total of 30 insurance companies, 24 of which are engaged in general insurance and 6 in life insurance (Source: Hisobotlar (2021) https://www.mf.uz/uz/otchety).

At the end of 2019, the insurance market of the country increased by 5.3 times compared to 2014 and amounted to 2313.9 billion sums ( $\$ 243 \mathrm{bln}$ ). The following diagram shows the dynamic change in insurance premiums calculated in the country since 2014 (Figure 1).

The main reason for the rapid change in insurance premiums, especially after 2017, can be explained by the increase in the number of insurance companies, the creation of conditions in the insurance market by the government, the formation of new types of insurance, increasing consumer interest in insurance products.

Nevertheless, there is work to be done in the field, and the following results can be obtained when assessing the insurance activity in the country based on new calculation standards above:

From our example, it can be seen that the density of total insurance premiums calculated by insurance companies in 2014-2019 has a dynamics of growth, comparing the population per capita from 14,401.24 UZS in 2014 to $69,579.47$ UZS in 2019. Assessing the density of the calculated insurance premium against the dollar, it is possible to determine that the population of the Republic of Uzbekistan in 2019 spent on insurance products on average in the amount of 7.31 USD. The figure averaged 63.19 USD in neighbouring Kazakhstan and 2.59 USD in Tajikistan (Table $1 \&$ Table 2).

Table 1. The share of insurance in the republic of Uzbekistan

\begin{tabular}{cccc}
\hline Years & Premiums & GDP & Penetration \\
\hline 2014 & 439.13 & $177,153.92$ & $0.25 \%$ \\
2015 & 551.53 & $210,183.10$ & $0.26 \%$ \\
2016 & 692.59 & $242,495.52$ & $0.29 \%$ \\
2017 & 927.45 & $302,536.82$ & $0.31 \%$ \\
2018 & 1635.20 & $406,648.50$ & $0.40 \%$ \\
2019 & 2313.90 & $511,838.09$ & $0.45 \%$ \\
\hline
\end{tabular}

Source: Data from the author. 
Table 2. The density of insurance premiums economy of the republic of Uzbekistan.

\begin{tabular}{ccccc}
\hline Years & Premiums & Population & Uzbek sum & USD \\
\hline 2014 & 439.13 & $30,492.80$ & $14,401.24$ & 1.51 \\
2015 & 551.53 & $31,022.50$ & $17,778.39$ & 1.87 \\
2016 & 692.59 & $31,575.30$ & $21,934.69$ & 2.30 \\
2017 & 927.45 & $32,120.50$ & $28,874.13$ & 3.03 \\
2018 & 1635.20 & 32656.70 & $50,072.42$ & 5.26 \\
2019 & 2313.90 & $32,255.50$ & $69,579.47$ & 7.31 \\
\hline
\end{tabular}

Source: Data from the author.

In this regard, one of the most important issues is to assess the contribution of insurance activity to the economy, which is reflected in the insurance market of Uzbekistan as follows:

The results of the study show that the insurance market of the Republic of Uzbekistan is not fully developed, and it is necessary to take large-scale measures to increase the volume of insurance. This is because the share of insurance in the economy in developed countries averages $7.2 \%$, while in developing countries it is around $2.7 \%$, while in the Republic of Uzbekistan by this figure was only $0.25 \%$ $0.45 \%$. The density of calculated insurance premiums in developed countries in 2014-2018 averaged 3402.1 - 3333.58 USD, while in developing countries this figure was about 129 USD, and in the insurance market of the Republic from 1.4 USD in 2014 to 7.31 USD in 2019 is proof of the relevance of such a calculation practice, which should be the main criterion for those who lead any insurance business $^{4}$ (Table 3) (Global Insurance Trends Analysis, 2018).

Here, the insurance premium is the sum of the total insurance premiums calculated during the selected years, as shown in the next example of the selected countries.

Insurance premium density is the ratio of the total insurance premiums calculated for a year to the GDP of the selected country is calculated and evaluated (Table 4).

Nevertheless, it can be seen from the diagram above that a positive trend has been achieved in the distribution of insurance premiums in the Republic of Uzbekistan in 2014-2019.Among the regions with a significant positive trend in terms of regions, the Tashkent has changed for the average (41.3 - 52.6) USD, Tashkent region (4.9 - 6.2) USD, Navoi region (3.8 - 7.4) USD. In the remaining regions, almost no significant changes were observed, but no negative trend was observed too.

Positive indicators were also observed in the dynamics of the share of insurance in the economy of Uzbekistan by regions, on average in the range of $0.295 \%$ to $0.529 \%$. In parallel with the above analysis, there is a serious positive trend in Tashkent $(1.111 \%-1.685 \%)$, Xorazm region $(0.184 \%-0.359 \%)$, Fergana region $(0.190 \%-0.377 \%)$, Tashkent region $(0.180 \%-0.340 \%)$. In Syrdarya region ${ }^{4}$ Source: Global Insurance Trends Analysis 2018: Pursuit of growth amid cautious optimism. 
Table 3. The share of insurance premiums penetration degree in developed countries (Insurance Indicators, https://stats.oecd.org/Index.aspx?DatasetCode=INSIND).

\begin{tabular}{|c|c|c|c|c|c|c|c|c|c|c|c|c|c|c|c|c|}
\hline \multirow{2}{*}{\multicolumn{2}{|c|}{ Countries }} & \multicolumn{3}{|c|}{2014} & \multicolumn{3}{|c|}{2015} & \multicolumn{3}{|c|}{2016} & \multicolumn{3}{|c|}{2017} & \multicolumn{3}{|c|}{2018} \\
\hline & & 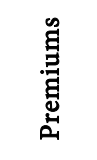 & 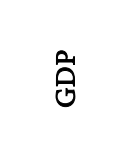 & 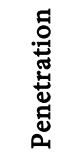 & 莺 & 苍 & 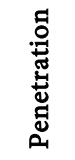 & 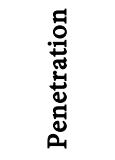 & $\begin{array}{l}\text { 品 } \\
\text { 营 } \\
\text { 离 }\end{array}$ & 今ิ & 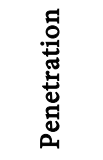 & $\begin{array}{l}\text { 咅 } \\
\text { 离 } \\
\text { 离 }\end{array}$ & 今ั & 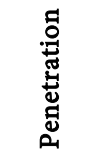 & 今ิ & 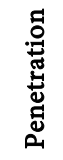 \\
\hline 1 & USA & 1280.4 & $17,521.75$ & $7 \%$ & 1316.7 & $18,219.3$ & $7 \%$ & 1352.4 & $18,707.19$ & $7 \%$ & 1377.1 & $19,485.39$ & $7 \%$ & 1469.4 & $20,494.1$ & $7 \%$ \\
\hline 2 & China & 328.44 & $10,482.37$ & $3 \%$ & 386.50 & $11,064.6$ & $3 \%$ & 466.13 & $11,190.99$ & $4 \%$ & 541.45 & $12,237.70$ & $4 \%$ & 574.88 & $13,608.2$ & $4 \%$ \\
\hline 3 & Japan & 479.76 & 4850.41 & $10 \%$ & 449.71 & 4394.98 & $10 \%$ & 471.30 & 4949.27 & $10 \%$ & 422.05 & 4872.42 & $9 \%$ & 440.65 & 4970.92 & $9 \%$ \\
\hline 4 & England & 351.27 & 3034.73 & $12 \%$ & 320.18 & 2896.42 & $11 \%$ & 304.21 & 2659.24 & $11 \%$ & 283.33 & 2637.87 & $11 \%$ & 336.51 & 2825.21 & $12 \%$ \\
\hline 5 & Franch & 270.52 & 2852.17 & $9 \%$ & 230.55 & 2438.21 & $9 \%$ & 237.64 & 2465.13 & $10 \%$ & 241.60 & 2582.50 & $9 \%$ & 257.96 & 2777.54 & $9 \%$ \\
\hline 6 & Germany & 254.65 & 3898.73 & $7 \%$ & 213.26 & 3381.39 & $6 \%$ & 215.02 & 3495.16 & $6 \%$ & 222.98 & 3693.20 & $6 \%$ & 241.49 & 3996.76 & $6 \%$ \\
\hline 7 & $\begin{array}{l}\text { South } \\
\text { Korea }\end{array}$ & 159.52 & 1411.33 & $11 \%$ & 153.62 & 1382.76 & $11 \%$ & 170.86 & 1414.80 & $12 \%$ & 181.22 & 1530.75 & $12 \%$ & 179.02 & 1619.42 & $11 \%$ \\
\hline 8 & Italy & 194.74 & 2151.73 & $9 \%$ & 165.04 & 1832.27 & $9 \%$ & 162.38 & 1869.12 & $9 \%$ & 155.51 & 1943.84 & $8 \%$ & 170.27 & 2073.90 & $8 \%$ \\
\hline \multirow[t]{2}{*}{9} & Canada & 125.37 & 1799.27 & $7 \%$ & 114.97 & 1552.52 & $7 \%$ & 114.52 & 1526.95 & $8 \%$ & 119.52 & 1647.12 & $7 \%$ & 127.90 & 1712.51 & $7 \%$ \\
\hline & & 3444.7 & $48,002.49$ & $7.2 \%$ & 3350.1 & $47,162.5$ & $7.1 \%$ & $34,494.5$ & $48,277.86$ & $7.2 \%$ & 3544.8 & $50,630.79$ & $7 \%$ & 3798.1 & $54,078.5$ & $7 \%$ \\
\hline
\end{tabular}

Source: Data from the author.

Table 4. Insurance premiums calculated by regions of the Republic of Uzbekistan and its distribution per capital.

(UZS and USD)

\begin{tabular}{|c|c|c|c|c|c|c|c|c|c|c|c|c|c|}
\hline & Insurance density & 2014 & 2015 & 2016 & 2017 & 2018 & 2019 & 2014 & 2015 & 2016 & 2017 & 2018 & 2019 \\
\hline 1 & Karakalpakstan & 6081.5 & 7147.7 & 9488.8 & $11,287.9$ & $23,974.7$ & $26,052.8$ & $\$ 2.5$ & $\$ 2.5$ & $\$ 2.9$ & $\$ 1.4$ & $\$ 2.9$ & $\$ 2.7$ \\
\hline 2 & Andijan region & 6799.7 & 8143.7 & $10,107.6$ & $13,373.1$ & $24,336.6$ & $26,837.3$ & $\$ 2.8$ & $\$ 2.9$ & $\$ 3.1$ & $\$ 1.6$ & $\$ 2.9$ & $\$ 2.8$ \\
\hline 3 & Bukhara region & 9854.5 & $11,966.9$ & $15,429.2$ & $19,124.1$ & $35,026.9$ & $42,525.3$ & $\$ 4.1$ & $\$ 4.3$ & $\$ 4.8$ & $\$ 2.4$ & $\$ 4.2$ & $\$ 4.5$ \\
\hline 4 & Jizzakh region & 6134.9 & 8766.3 & $12,039.7$ & $14,549.8$ & $27,086.9$ & $43,642.5$ & $\$ 2.5$ & $\$ 3.1$ & $\$ 3.7$ & $\$ 1.8$ & $\$ 3.2$ & $\$ 4.6$ \\
\hline 5 & Qashqadaryo region & 6372.6 & 7401.8 & 9464.1 & $10,588.3$ & $17,623.4$ & $23,899.7$ & $\$ 2.6$ & $\$ 2.6$ & $\$ 2.9$ & $\$ 1.3$ & $\$ 2.1$ & $\$ 2.5$ \\
\hline 6 & Navoiy region & 9316.6 & $11,616.0$ & $17,075.3$ & $21,502.2$ & $53,406.6$ & $70,765.8$ & $\$ 3.8$ & $\$ 4.1$ & $\$ 5.3$ & $\$ 2.6$ & $\$ 6.4$ & $\$ 7.4$ \\
\hline 7 & Namangan region & 5918.8 & 7360.2 & 9733.6 & $10,923.7$ & $22,637.5$ & $33,490.1$ & $\$ 2.4$ & $\$ 2.6$ & $\$ 3.0$ & $\$ 1.3$ & $\$ 2.7$ & $\$ 3.5$ \\
\hline 8 & Samarqand region & 5609.6 & 6381.8 & 8297.2 & $10,648.7$ & $19,087.6$ & $21,786.9$ & $\$ 2.3$ & $\$ 2.3$ & $\$ 2.6$ & $\$ 1.3$ & $\$ 2.3$ & $\$ 2.3$ \\
\hline 9 & Surxondaryo region & 4926.4 & 5989.8 & 8006.1 & 8126.8 & $18,255.8$ & $24,427.1$ & $\$ 2.0$ & $\$ 2.1$ & $\$ 2.5$ & $\$ 1.0$ & $\$ 2.2$ & $\$ 2.6$ \\
\hline 10 & Sirdaryo region & 9217.2 & $11,906.7$ & $13,366.1$ & $12,585.9$ & $29,937.9$ & $49,214.8$ & $\$ 3.8$ & $\$ 4.2$ & $\$ 4.1$ & $\$ 1.5$ & $\$ 3.6$ & $\$ 5.2$ \\
\hline 11 & Tashkent region & $11,765.9$ & $14,352.7$ & $18,589.3$ & $24,442.5$ & $39,747.4$ & $58,792.4$ & $\$ 4.9$ & $\$ 5.1$ & $\$ 5.8$ & $\$ 3.0$ & $\$ 4.8$ & $\$ 6.2$ \\
\hline 12 & Fergana region & 7321.6 & 8290.6 & $10,719.9$ & $13,968.1$ & $24,822.1$ & $33,674.8$ & $\$ 3.0$ & $\$ 3.0$ & $\$ 3.3$ & $\$ 1.7$ & $\$ 3.0$ & $\$ 3.5$ \\
\hline 13 & Xorazm region & 7567.1 & 9144.5 & $12,750.2$ & $15,619.1$ & $29,558.7$ & $37,393.0$ & $\$ 3.1$ & $\$ 3.3$ & $\$ 3.9$ & $\$ 1.9$ & $\$ 3.5$ & $\$ 3.9$ \\
\hline \multirow[t]{2}{*}{14} & Tashkent & $100,150.5$ & $127,516.2$ & $151,090.6$ & $212,647.4$ & $344,964.3$ & $500,223.2$ & $\$ 41.3$ & $\$ 45.4$ & $\$ 46.8$ & $\$ 26.2$ & $\$ 41.4$ & $\$ 52.6$ \\
\hline & Everage & $14,401.2$ & $17,778.4$ & $21,934.7$ & $28,874.1$ & $50,072.3$ & $69,579.6$ & $\$ 5.9$ & $\$ 6.3$ & $\$ 6.8$ & $\$ 3.6$ & $\$ 6.0$ & $\$ 7.3$ \\
\hline
\end{tabular}

Source: Data from the author. 
$(0.183 \%-0.390 \%)$, Namangan region $(0.178 \%-0.397 \%)$, Jizzakh region $(0.142 \%$ - $0.388 \%$ ) can be evaluated using Table 5 below.

While this analysis is examined among developed countries on a selective basis, the ratio of insurance in the economy, or the selected country's GDP, averaged around $\$ 3402.95$ in 2014 , around $\$ 3333.58$ in 2018 , as well as selected countries' annuals. The density of total insurance premiums calculated during the period also averaged $7 \%$, respectively.

It was found that the selected countries have a direct correlation between the calculated insurance premium density for the respective years and its share in GDP, averaging $70 \%$ to $78 \%$. Hence, we can scientifically conclude that the higher the density of the calculated insurance premiums, the higher its share in the economy. The following Table 6 is an overview of insurance activity in these selected countries.

Reforms in the field of insurance in Uzbekistan are reflected in the laws, decisions and decrees adopted by our government to offer insurance products that can meet the requirements of their scale and time, to provide maximum protection of insurers from financial risks.

This can be seen in the following documents:

- Civil Code of the Republic of Uzbekistan (Chapter 52 "Insurance");

- Law of the Republic of Uzbekistan "On insurance activity" (05.04.2002 N 358-II);

Table 5. The insurance penetrations in the economy calculated by regions of the country (Source: O'Zbekiston Respublikasi Davlat Statistika Qo 'Mitasi, https://stat.uz/uz).

\begin{tabular}{cccccccc}
\hline Insurance penetration & 2014 & $\mathbf{2 0 1 5}$ & $\mathbf{2 0 1 6}$ & $\mathbf{2 0 1 7}$ & $\mathbf{2 0 1 8}$ & $\mathbf{2 0 1 9}$ \\
\hline 1 & Karakalpakstan & $0.210 \%$ & $0.202 \%$ & $0.211 \%$ & $0.200 \%$ & $0.294 \%$ & $0.260 \%$ \\
2 & Andijan region & $0.166 \%$ & $0.173 \%$ & $0.188 \%$ & $0.206 \%$ & $0.277 \%$ & $0.250 \%$ \\
3 & Bukhara region & $0.178 \%$ & $0.181 \%$ & $0.203 \%$ & $0.214 \%$ & $0.310 \%$ & $0.302 \%$ \\
4 & Jizzakh region & $0.142 \%$ & $0.173 \%$ & $0.209 \%$ & $0.207 \%$ & $0.297 \%$ & $0.388 \%$ \\
5 & Qashqadaryo region & $0.132 \%$ & $0.133 \%$ & $0.149 \%$ & $0.144 \%$ & $0.198 \%$ & $0.211 \%$ \\
6 & Navoiy region & $0.095 \%$ & $0.104 \%$ & $0.137 \%$ & $0.142 \%$ & $0.231 \%$ & $0.189 \%$ \\
7 & Namangan region & $0.178 \%$ & $0.183 \%$ & $0.208 \%$ & $0.200 \%$ & $0.339 \%$ & $0.397 \%$ \\
8 & Samarqand region & $0.132 \%$ & $0.128 \%$ & $0.136 \%$ & $0.152 \%$ & $0.227 \%$ & $0.220 \%$ \\
9 & Surxondaryo region & $0.130 \%$ & $0.134 \%$ & $0.167 \%$ & $0.146 \%$ & $0.258 \%$ & $0.281 \%$ \\
10 & Sirdaryo region & $0.183 \%$ & $0.195 \%$ & $0.185 \%$ & $0.157 \%$ & $0.303 \%$ & $0.390 \%$ \\
11 & Tashkent region & $0.180 \%$ & $0.188 \%$ & $0.229 \%$ & $0.248 \%$ & $0.293 \%$ & $0.340 \%$ \\
12 & Fergana region & $0.190 \%$ & $0.182 \%$ & $0.217 \%$ & $0.251 \%$ & $0.338 \%$ & $0.377 \%$ \\
13 & Xorazm region & $0.184 \%$ & $0.185 \%$ & $0.228 \%$ & $0.242 \%$ & $0.350 \%$ & $0.359 \%$ \\
14 & Tashkent & $1.111 \%$ & $1.155 \%$ & $1.092 \%$ & $1.266 \%$ & $1.555 \%$ & $1.685 \%$ \\
& Everage & $\mathbf{0 . 2 9 5 \%}$ & $\mathbf{0 . 3 0 8 \%}$ & $\mathbf{0 . 3 3 0 \%}$ & $\mathbf{0 . 3 6 8 \%}$ & $\mathbf{0 . 4 8 8} \%$ & $\mathbf{0 . 5 2 9} \%$ \\
\hline
\end{tabular}

Source: Data from the author. 
Table 6. Correlation between insurance premiums per capita in developed countries and its share in GDP.

\begin{tabular}{|c|c|c|c|c|c|c|c|c|c|c|c|}
\hline & \multirow[b]{2}{*}{ Countries } & \multicolumn{2}{|c|}{2014} & \multicolumn{2}{|c|}{2015} & \multicolumn{2}{|c|}{2016} & \multicolumn{2}{|c|}{2017} & \multicolumn{2}{|c|}{2018} \\
\hline & & $\begin{array}{l}\text { Premiums } \\
\text { share on } \\
\text { population }\end{array}$ & Penetration & $\begin{array}{l}\text { Premiums } \\
\text { share on } \\
\text { population }\end{array}$ & Penetration & $\begin{array}{l}\text { Premiums } \\
\text { share on } \\
\text { population }\end{array}$ & Penetration & $\begin{array}{l}\text { Premiums } \\
\text { share on } \\
\text { population }\end{array}$ & Penetration & $\begin{array}{l}\text { Premiums } \\
\text { share on } \\
\text { population }\end{array}$ & Penetration \\
\hline 1 & USA & 4042.11 & $7 \%$ & 4102.09 & $7 \%$ & 4186.74 & $7 \%$ & 4236.17 & $7 \%$ & 4492.18 & $7 \%$ \\
\hline 2 & China & 240.79 & $3 \%$ & 274.73 & $3 \%$ & 329.64 & $4 \%$ & 381.03 & $4 \%$ & 402.67 & $4 \%$ \\
\hline 3 & Japan & 3768.81 & $10 \%$ & 3513.74 & $10 \%$ & 3688.82 & $10 \%$ & 3310.13 & $9 \%$ & 3464.15 & $9 \%$ \\
\hline 4 & England & 5458.58 & $12 \%$ & 4861.47 & $11 \%$ & 4588.50 & $11 \%$ & 4246.11 & $11 \%$ & 5011.94 & $12 \%$ \\
\hline 5 & Franch & 4088.51 & $9 \%$ & 3576.94 & $9 \%$ & 3674.84 & $10 \%$ & 3726.00 & $9 \%$ & 3969.24 & $9 \%$ \\
\hline 6 & Germany & 3152.82 & $7 \%$ & 2607.53 & $6 \%$ & 2616.03 & $6 \%$ & 2697.58 & $6 \%$ & 2905.10 & $6 \%$ \\
\hline 7 & South Korea & 3143.36 & $11 \%$ & 3022.64 & $11 \%$ & 3351.34 & $12 \%$ & 3546.57 & $12 \%$ & 3498.48 & $11 \%$ \\
\hline 8 & Italy & 3203.79 & $9 \%$ & 2724.35 & $9 \%$ & 2676.80 & $9 \%$ & 2563.04 & $8 \%$ & 2808.54 & $8 \%$ \\
\hline \multirow[t]{2}{*}{9} & Canada & 3527.80 & $7 \%$ & 3191.19 & $7 \%$ & 3147.71 & $8 \%$ & 3253.80 & $7 \%$ & 3449.89 & $7 \%$ \\
\hline & & 3402.95 & $7.2 \%$ & 3097.19 & $7.1 \%$ & 3140.05 & $7.2 \%$ & 3106.71 & $7.0 \%$ & 3333.58 & $7.0 \%$ \\
\hline \multicolumn{2}{|c|}{ Correlation (\%) } & & $78 \%$ & & $75 \%$ & & $73 \%$ & & $70 \%$ & & $75 \%$ \\
\hline
\end{tabular}

Source: Data from the author.

- Resolution of the President of the Republic of Uzbekistan dated 21.05.2008 RP-872 "On additional measures for further reform and development of the market of insurance services";

- Resolution of the President of the Republic of Uzbekistan dated 31.05.2011 RP-1544"On additional measures to further increase the financial stability of insurers";

- Decree of the President of the Republic of Uzbekistan dated 31.01.2002 PD-3022 "On measures to further liberalize and develop the insurance market";

- Resolution of the Cabinet of Ministers of the Republic of Uzbekistan dated 21.04.1998 No. 167 "On measures to ensure insurance of national exporters" and others.

\section{Results}

There are many insurance organizations, companies such as Uzagrosugurta JSC, Uzbekinvest NEIIC, Alfa Invest LLC, which are leaders in the insurance market of the Republic of Uzbekistan, were selected to analyze the insurance portfolio, to assess the relevance of the above-mentioned calculation tools for new calculations, and the following results were determined.

Example 1. The results of the critical analysis of the insurance portfolio of JSC "Uzagrosugurta" for 2016 are as follows ${ }^{5}$ (Figure 2 \& Figure 3).

The company is one of the leading insurance companies in the country, operating in the insurance market of Uzbekistan with its insurance products. To ${ }^{5}$ Source: CICLVO-The Law of the Republic of Uzbekistan on Compulsory Insurance of Civil Liability of Vehicle Owners №O’RQ-155 dated April 21, 2008. 


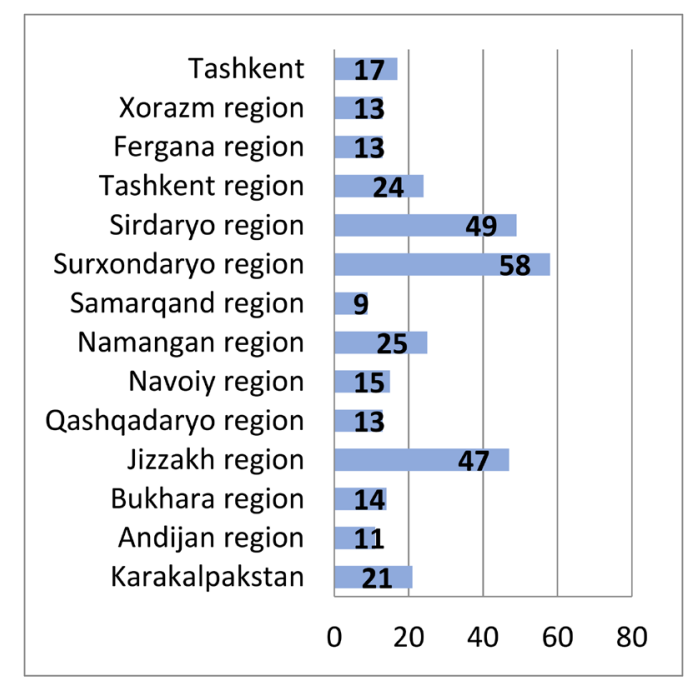

Source: Data from the author.

Figure 2. The loss rate of insurance premiums of the Company's insurance portfolio in 2016.

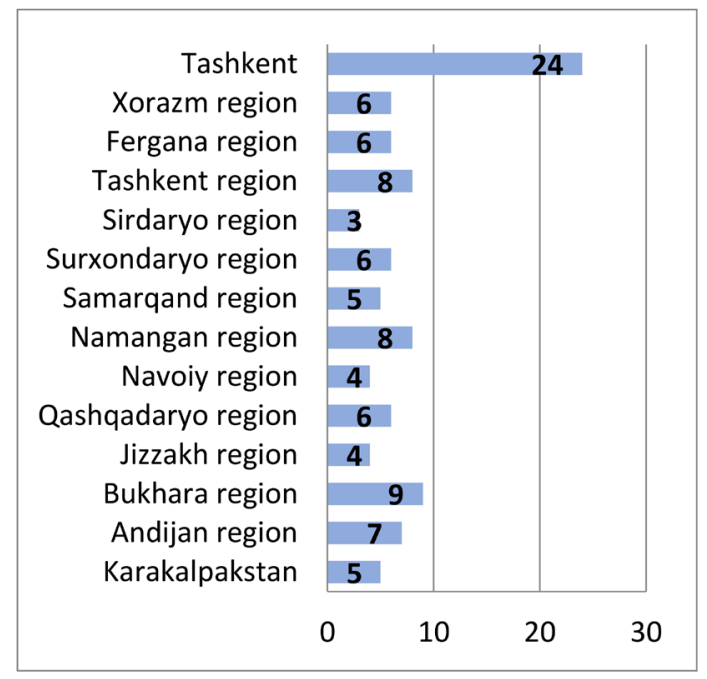

Source: Data from the author.

Figure 3. The territorial distribution of insurance premiums calculated by the Company for non compulsory insurance in 2016.

date, the company's insurance portfolio specializes in general and compulsory types of insurance.

In the process of traditional analysis, the Company's insurance products were based on quantitative and percentage indicators by regions, for different financial reporting periods. The volume of insurance contracts, insurance liabilities, insurance claims, their resolution, the level of loss of the insurance portfolio, and the tasks performed to reduce it are described in detail in the section on insurance products. Regions play a key role in the company's insurance portfolio, accounting for $76 \%$ of total insurance premiums calculated during the year.

Among the regions, the Tashkent region (8\%), the Namangan region (8\%), 
and the Bukhara region (9\%) were the leaders. The remaining regions also had a share of at least $3 \%$ to more than $6 \%$ in the insurance portfolio (Figure 3 ).

The level of loss of total insurance premiums in the insurance portfolio of the company is also reflected in the regions by $49 \%$ in Syrdarya region, $58 \%$ in Surkhandarya region, $47 \%$ in Jizzakh region, $25 \%$ in Namangan region, $24 \%$ in Tashkent region and $21 \%$ in Karakalpakstan $21 \%$, these regions are distinguished by the fact that insurance premiums have the highest loss rates in the analyzed year. In the rest of the regions, respectively, the loss rates of insurance premiums ranged from a minimum of $9 \%$ to a maximum of $17 \%$ (Figure 2).

It should be noted that the share of insurance contracts with legal entities in the total insurance portfolio of the Company is lower than the number of insurance contracts with individuals, which can be explained by the fact that individuals play a key role in compulsory insurance contracts. In 2016, the Tashkent was the leader in the number of insurance contracts concluded by the Company with legal entities, accounting for $20 \%$ of the total number of insurance contracts. The territorial departments of the Company should take the necessary measures to expand the scope of contracts with legal entities, to address issues of wide involvement of existing legal entities in the insurance process in the regions.

The results of the analysis show that in 2016, the share of insurance of individuals under the type of "Compulsory Insurance of Civil Liability of Vehicle Owners" directly affected the number of insurance contracts with individuals in the total insurance portfolio of the Company, ranging from $80 \%$ to $98 \%$ in all regions is proof of our opinion (Figure 5). The analysis of insurance liabilities by regions also focuses on the extent to which the Company has insurance liabilities. This indicator reflects the insurer's ability to pay and provides an opportunity to verify the fulfilment of obligations. As can be seen from the diagram below, the

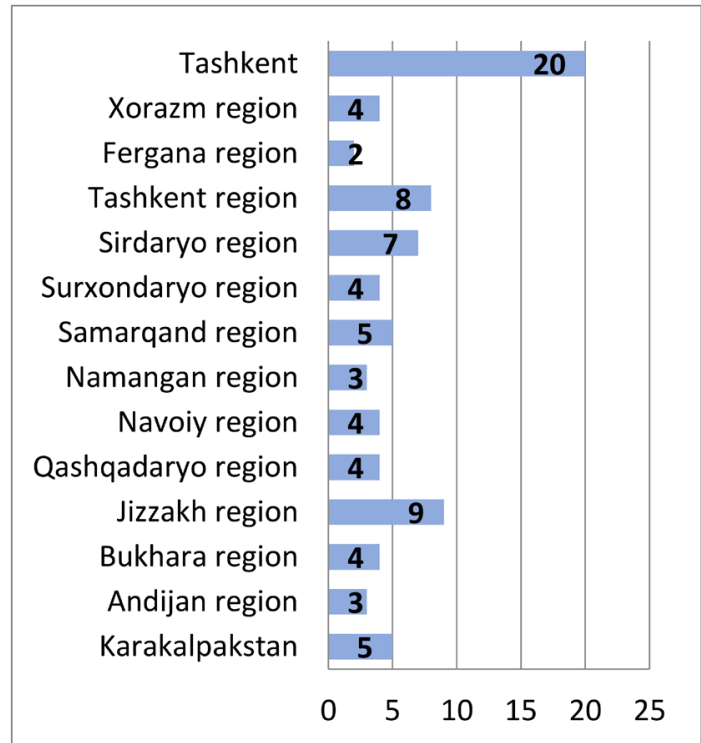

Source: Data from the author.

Figure 4. Share of contracts with legal entities in insurance contracts \% (2016). 


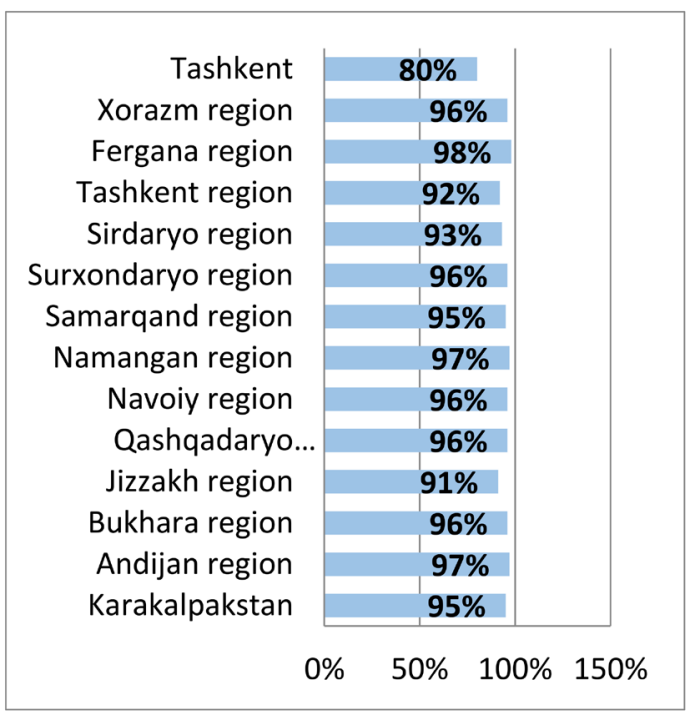

Source: Data from the author.

Figure 5. Share of contracts with individuals in insurance contracts \% (2016).

Tashkent dominates the Company's insurance portfolio with the largest number of insurance liabilities, covering $34 \%$ of the total insurance portfolio.

The remaining areas ranged from a minimum of $2 \%$ to a maximum of $8 \%$. This means that the Tashkent plays a key role in terms of the level of insurance risk (Figure 4).

We know that the share of insurance agents and employees in the accumulation of insurance premiums in insurance companies is high.

Because the bulk of insurance contracts are searched by these entities for insurance objects and contracts are concluded. Appropriate measures have been taken to encourage and support insurance agents in the Company which can be concluded from the position of the Company in the state unit.

The share of compulsory insurance in the company's insurance portfolio should be recognized by insurance and others. The distribution of total insurance premiums and accrued insurance liabilities for these types of insurance is clearly shown in the diagram below.

The leading type of insurance premiums calculated by types of compulsory insurance is "Compulsory Insurance of Civil Liability of Employers", which in 2016 amounted to $65 \%$ of all types of compulsory insurance. The next place is occupied by "Compulsory Insurance of Civil Liability of Vehicle Owners" with 18\% (Figures 6-9). The share of individuals in the number of insurance claims settled by type of compulsory insurance was high, which was 59\% in the Samarkand region, $52 \%$ in the Andijan region, and $46 \%$ in the Tashkent region.

When analyzing insurance claims received by company data, the main focus was on the level of satisfaction of claims. As can be seen from the diagrams below, almost all of the total number of claims received have been satisfied. Surkhandarya region accounted for the largest share of insurance claims, which amounted to $11.71 \%$, and Navoi region - 5.29\%. In the remaining areas, almost 


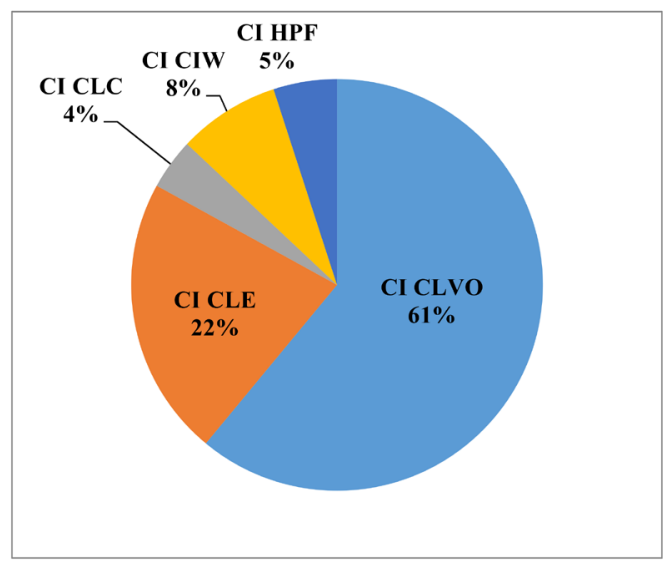

CICLE-The Law of the Republic of Uzbekistan on Compulsory Insurance of Civil Liability of Employers № O’RQ—210 dated April 16, 2009; Source: Data from the author.

Figure 6. Share of individuals in settled insurance compulsory insurance \% (2016).

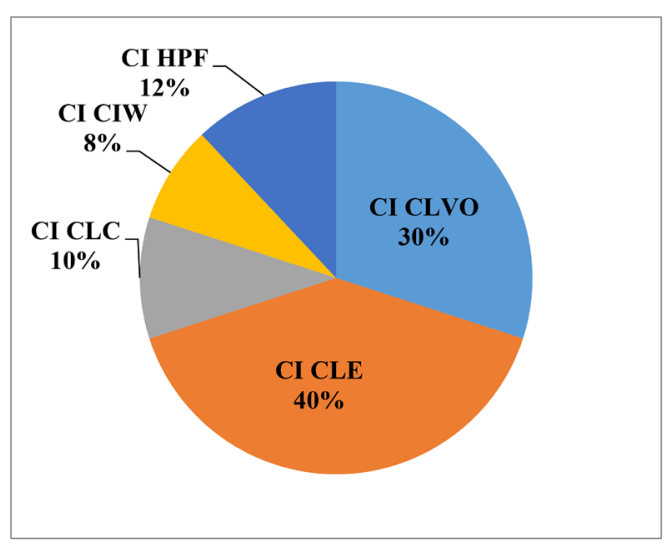

CICLC-Law of the Republic of Uzbekistan on Compulsory Insurance of Civil Liability of Carriers № O'RQ-386 dated May 26, 2015; CICIW-Compulsory Insurance of Construction and Installation Works; CIHPF-Compulsory Insurance of Hazardous Production Facilities. Source: Data from the author.

Figure 7. The loss rate of insurance premiums of claims \% (2016).

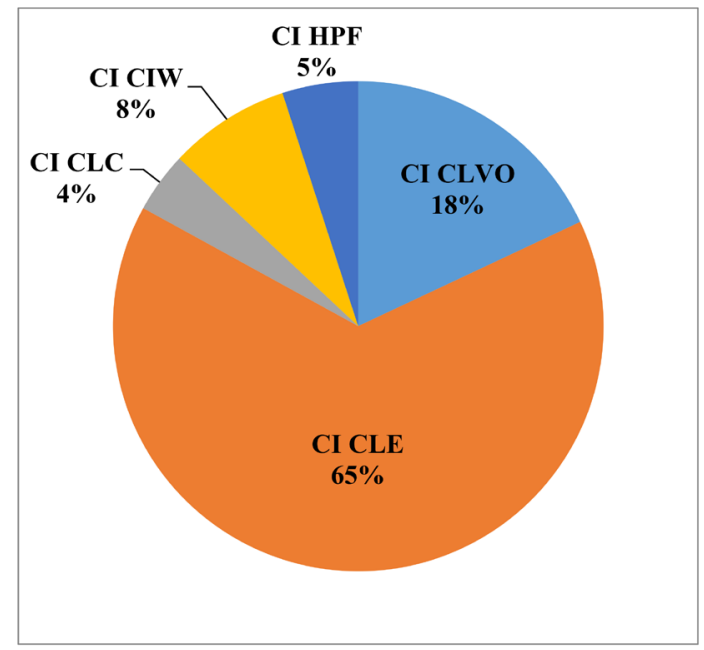

Source: Data from the author.

Figure 8. Distribution of insurance premiums compulsory insurance \% (2016). 


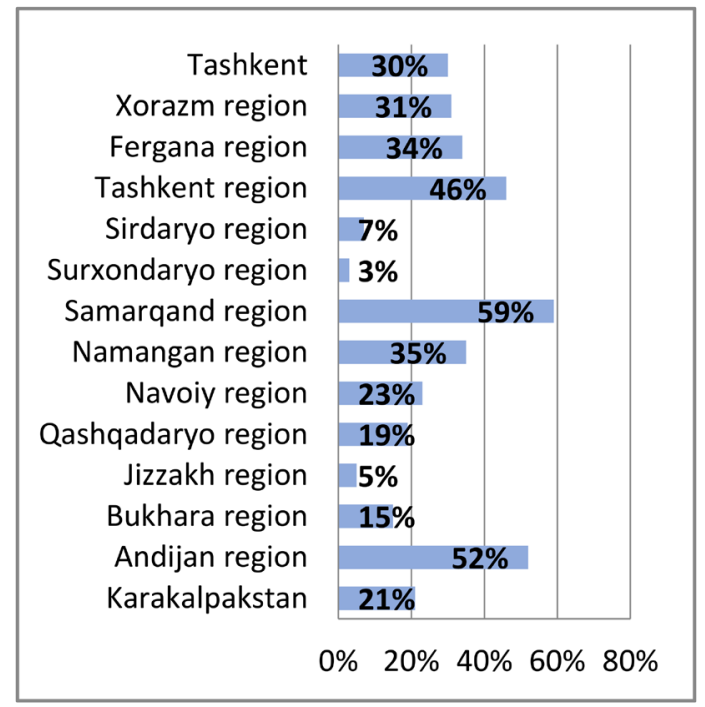

Source: Data from the author.

Figure 9. Distribution of insurance liabilities of compulsory insurance \% (2016).

all insurance claims were satisfied. The process of dealing with insurance claims in the insurance business is also the most important, but also a responsible process, which has a great impact on the insurer's ability to justify the trust of future customers, to conclude more insurance contracts. Because one of the main criteria in the insurance business is customer trust. In this regard, the Company has carried out significant reforms and measures

Example 2. The role of probability theory in the calculation of insurance tariff coefficients, in assessing the level of risk of insurance objects is unique. Below we consider the question of how to assess the object of insurance, its level of damage, and tariff coefficients based on the principals of probability theory. It will be find by following example.

The insured value of the facility is $20,000,000$ units, the probability of damage from storms within a year is estimated at $3 \%$, the probability of damage from floods is $2 \%$, and the probability of damage from fire is estimated at $1 \%$. Assuming that all the listed events occur independently of each other, it is necessary to determine the following:

1) Find the risky part of the insurance premium calculated for the object in case of occurrence of at least one of the three events listed;

2) Find out the risk insurance premium of the object when it is insured on one sheet of all listed risks.

Probability theory as we know it is one of the natural sciences based on calculating the probability of occurrence or non-occurrence of events and happenings in real life and theoretically evaluating probability cases.

In this example, we can identify the events of damage to the facility from future storms, floods, and fires with conditional symbols such as $B_{1}, B_{2}, B_{3}$, respectively. And we denote by $A_{1}$ the probability that at least one of these events will occur and by $A_{2}$ the probability that all three events will occur at once. 
According to probability theory, the probability that at least one of the unrelated events will occur is equal to the product of the probabilities that these events will occur. That is:

$$
\begin{gathered}
\bar{A}_{1}=\bar{B}_{1} * \bar{B}_{2} * \bar{B}_{3} \text {, here (Lindholm \& Verrall, 2020) } \\
P\left(B_{1}\right)=0.03 ; P\left(B_{2}\right)=0.02 ; P\left(B_{3}\right)=0.01 . \\
P\left(\bar{A}_{1}\right)=P\left(\bar{B}_{1}\right) * P\left(\bar{B}_{2}\right) * P\left(\bar{B}_{3}\right)=\left(1-P\left(\bar{B}_{1}\right)\right) *\left(1-P\left(\bar{B}_{2}\right)\right) *\left(1-P\left(\bar{B}_{3}\right)\right) \\
=(1-0.03) *(1-0.02) *(1-0.01)=0.941094 \\
P\left(A_{1}\right)=1-P\left(\bar{A}_{1}\right)=1-0.941094=0.058906
\end{gathered}
$$

Hence, when the object is insured under the first condition of the matter, the risk-related part of the insurance premium is calculated as follows:

$$
R_{p 1}=\text { Object value } * P\left(A_{1}\right)=20000000 * 0.058906=1178120 .
$$

Also, according to the second condition of the issue, when calculating the insurance premium on the probability of occurrence of all the events listed at once, it will have the following form:

$$
\begin{gathered}
A_{2}=B_{1} * B_{2} * B_{3}, \\
P\left(A_{2}\right)=P\left(B_{1} * B_{2} * B_{3}\right)=P\left(B_{1}\right) * P\left(B_{2}\right) * P\left(B_{3}\right) \\
=0.03 * 0.02 * 0.01=0.000006 \\
R_{p 2}=\text { Object value } * P\left(A_{2}\right)=20000000 * 0.000006=120 .
\end{gathered}
$$

The solution to the problem also shows that the value of the insurance premium is also high because the probability of loss when insured is high, provided that one of the three events occurs. Because it is very rare for the three events listed to occur at once.

Example 3. Among the final indicators of insurance activity, the indicators of total calculated insurance premiums and total paid insurance indemnities are widely used, as well as among the most important indicators. Using these indicators, it is important to determine the tariff rate for the selected type of insurance for the next year, which can have a direct impact on the insurance portfolio for the next year, the plan of insurance premiums to be accumulated. We will look at this in more detail using the following example.

The issue of setting the insurance tariff rate for the next year based on the insurance statistics of the company formed during 2002-2006 (Table 7).

Table 7. Insurance indemnity and liability statistics for 2002-2006.

\begin{tabular}{cccc}
\hline T.p & Years & Total calculated insurance liability & Total calculated insurance indemnity \\
\hline 1 & 2002 & $20,000,000$ & 400,000 \\
2 & 2003 & $28,000,000$ & 700,000 \\
3 & 2004 & $25,000,000$ & 800,000 \\
4 & 2005 & $30,000,000$ & 900,000 \\
5 & 2006 & $35,000,000$ & $1,400,000$
\end{tabular}

Source: Data from the author. 
The level of loss of the sum insured (the notation is included by $Y$ ) is defined as the ratio of insurance indemnity to the insurance liability and is expressed by the following formula:

$$
Y=\frac{S_{b}}{S} \quad(\text { Lindholm \& Verrall, 2020) }
$$

The forecast of the insurance tariff rate for the next new year is made by constructing a linear regression equation, and the time dependence of the level of loss is assessed as linearly significant. The main part of the insurance premium is the $T_{o}$ Netto Premium, which represents the level of damage of the insurance premium, i.e.:

$$
T_{o}=\frac{S_{b}}{S} * 100, \text { or } T_{o}=Y * 100
$$

Based on this formula, we calculate the loss rates of insurance liabilities over the years (Table 8).

Linear regression equation:

$Y_{i}=a_{o}+a_{1} * i$ perform several computational operations based on the conditions of the above problem and the theory of the construction of a straight-line regression equation, the methods of least squares.

$$
D=D\left(a_{o} * a_{1}\right)=\sum_{i=1}^{5}\left(Y_{i}-Y_{i}^{*}\right)=\sum_{i=1}^{5}\left(Y_{i}-a_{o}-a_{1} * i\right)^{2}
$$

And from here we determine the basic parameters of the linear trend $a_{o}$ and $a_{1}$. To determine $a_{o}$ and $a_{1}$ with the least error, we can differentiate this equation and have the following:

$$
\left\{\begin{array}{l}
\frac{\mathrm{d} D}{\mathrm{~d} a_{o}}=\frac{\mathrm{d}}{\mathrm{d} a_{o}}\left[\sum_{i=1}^{5}\left(Y_{i}-a_{o}-a_{1} * i\right)^{2}\right]^{2}=-2 \sum_{i=1}^{5}\left(Y_{i}-a_{o}-a_{1} * i\right)^{2}=0 \\
\frac{\mathrm{d} D}{\mathrm{~d} a_{1}}=\frac{\mathrm{d}}{\mathrm{d} a_{1}}\left[\sum_{i=1}^{5}\left(Y_{i}-a_{o}-a_{1} * i\right)^{2}\right]^{2}=-2 \sum_{i=1}^{5}\left(Y_{i}-a_{o}-a_{1} * i\right) i=0
\end{array}\right.
$$

We can simplify this system of differential equations in the following view:

$$
\begin{aligned}
& \left\{\sum_{i=1}^{5} Y_{i}=\sum_{i=1}^{5}\left(a_{o}+a_{1} * i\right)=5 a_{o}+a_{1} \sum_{i=1}^{5} i\right. \\
& \sum_{i=1}^{5} i Y_{i}=\sum_{i=1}^{5}\left(a_{o} i+a_{1} * i^{2}\right)=a_{o} \sum_{i=1}^{5} i+a_{1} \sum_{i=1}^{5} i^{2} \\
& \left\{\begin{array}{l}
5 a_{o}+a_{1} \sum_{i=1}^{5} i=\sum_{i=1}^{5} Y_{i} \\
a_{o} \sum_{i=1}^{5} i+a_{1} \sum_{i=1}^{5} i^{2}=\sum_{i=1}^{5} i Y_{i}
\end{array}\right.
\end{aligned}
$$

Table 8. Degree of loss of insurance liability for 2001-2005.

\begin{tabular}{cccccc}
\hline$i$ & 2002 & 2003 & 2004 & 2005 & 2006 \\
$\left(Y_{i}\right)$ & 0.02 & 0.025 & 0.032 & 0.03 & 0.04 \\
\hline
\end{tabular}

Source: Data from the author. 
In the general case, when all the statistics are known, the system of equations for several $\mathrm{n}$ years will have the following appearance:

$$
\left\{\begin{array}{l}
n a_{o}+a_{1} \sum_{i=1}^{n} i=\sum_{i=1}^{n} Y_{i} \\
a_{o} \sum_{i=1}^{n} i+a_{1} \sum_{i=1}^{n} i^{2}=\sum_{i=1}^{n} i Y_{i}
\end{array}\right.
$$

We will now calculate the above problem based on this formula:

Based on the final summary data of (Table 9), we construct the following regression equation:

$$
\left\{\begin{array}{l}
5 a_{o}+15 a_{1}=0.147 \\
15 a_{o}+55 a_{1}=0.486
\end{array}\right.
$$

From here,

$$
\left\{\begin{array}{l}
a_{o}=0.0024 \\
a_{1}=0.009
\end{array}\right.
$$

Besides, from this, we can construct the following linear regression equation:

$$
Y_{i}^{*}=0.0024+0.009 * i
$$

We calculate the insurance rate for the new 6 years $(i=6)$ :

$$
Y_{i}^{*}=0.0024+0.009 * 6=0.0564
$$

To determine the principal part $\left(T_{o}\right)$ of the net reward $\left(T_{n}\right)$, multiply $Y^{*}$ by 100 units. So,

$$
T_{o}=0.0564 * 100=5.64
$$

To calculate the insurance premium, it is necessary to determine the risk premium of the insurance premium. We can define this as $T_{p}$. To do this, we calculate the standard deviation of the indemnity level of liability as follows (Table 10):

$$
\begin{gathered}
\sigma=\sqrt{\frac{1}{n-1} \sum_{i=1}^{n}\left(Y_{i}-Y_{i}^{*}\right)^{2}} \\
\sigma=\sqrt{\frac{1}{5-1} \sum_{i=1}^{5}\left(Y_{i}-Y_{i}^{*}\right)^{2}}=\sqrt{\frac{0.0000247}{4}}=0.0024
\end{gathered}
$$

Table 9. Calculation of the coefficients of linear regression equation.

\begin{tabular}{ccccc}
\hline Years & $\boldsymbol{i}$ & $\boldsymbol{Y}_{\boldsymbol{i}}$ insurance liability degree of damage & $\boldsymbol{i} \boldsymbol{Y}_{\boldsymbol{i}}$ & $\boldsymbol{I}^{2}$ \\
\hline 2002 & 1 & 0.020 & 0.020 & 1 \\
2003 & 2 & 0.025 & 0.050 & 4 \\
2004 & 3 & 0.032 & 0.096 & 9 \\
2005 & 4 & 0.030 & 0.120 & 16 \\
2006 & 5 & 0.040 & 0.200 & 25 \\
Total & $\mathbf{1 5}$ & $\mathbf{0 . 1 4 7}$ & $\mathbf{0 . 4 8 6}$ & $\mathbf{5 5}$ \\
\hline
\end{tabular}

Source: Data from the author. 
Table 10. Calculation of average quadratic differentiation of linear regression equation.

\begin{tabular}{ccccc}
\hline $\boldsymbol{i}$ & $Y_{i}$ & $Y_{i}^{*}$ & $Y_{i}^{*}-Y_{i}$ & $\left(Y_{i}-Y_{i}^{*}\right)^{2}$ \\
\hline $\mathbf{1}$ & 0.020 & 0.0204 & +0.0004 & 0.00000016 \\
$\mathbf{2}$ & 0.025 & 0.0249 & -0.0001 & 0.00000001 \\
$\mathbf{3}$ & 0.032 & 0.0294 & -0.0026 & 0.00000676 \\
$\mathbf{4}$ & 0.030 & 0.0339 & +0.0039 & 0.00001521 \\
$\mathbf{5}$ & 0.040 & 0.0384 & -0.0016 & 0.00000256 \\
Total & & & & $\mathbf{0 . 0 0 0 0 2 4 7 0}$ \\
\hline
\end{tabular}

Source: Data from the author.

Table 11. Dependence of $\beta(y, n)$.

\begin{tabular}{cccccc}
\hline$n / y$ & 0.8 & 0.9 & 0.95 & 0.975 & 0.99 \\
3 & 2.972 & 6.649 & 13.640 & 27.448 & 68.740 \\
4 & 1.592 & 2.829 & 4.380 & 6.455 & 10.448 \\
5 & 1.184 & $\underline{\mathbf{1 . 9 8 4}}$ & 2.850 & 3.854 & 5.500 \\
6 & 0.980 & 1.596 & 2.219 & 2.889 & 3.900 \\
\hline
\end{tabular}

Source: Data from the author.

We now calculate the risk premium of the direct insurance premium based on the following formula:

$$
T_{p}=\beta(y, n) * \sigma \quad(\text { Lindholm \& Verrall, 2020) }
$$

Here $\beta(y, n)$ is the value between the security guarantee indicator and the years, expressing the level of confidence of the insurance company to cover the insured events that the insurance premium collected with probability $y=0.9$, and the degree of dependence of the events when $y=0.9$ and $n=5$ for the selected issue $\mathrm{b}(y, n)$ are selected from (Table 11).

$$
\begin{gathered}
\beta(0.9,5)=1.984 \\
T_{p}=\beta(y, n) * \sigma=1.984 * 0.0024=0.047 \\
T_{n}=T_{o}+T_{p}=5.64+0.047=5.687
\end{gathered}
$$

If the insurance premium is loaded at $30 \%$, the insurance premium rate coefficient will be as follows:

$$
T_{\Delta}=\frac{T_{n}}{100-30} * 100=\frac{5.687}{70} * 100=8.124
$$

Example 4.The insured the object with a value of 450,000 units based on the distribution of 100,000,200,000, and 300,000 units of currency in the insurance companies $S_{1}, S_{2}, S_{3}$, respectively. As a result of the insured event, the whole insured object was destroyed. It is necessary to determine the amount of insurance indemnity to be paid by each insurance company (Silvestrov \& Martin-Löf, 2014).

Initially, the total insurance liabilities of each $S_{1}, S_{2}, S_{3}$ insurance company are 
determined:

$S=100,000+200,000+300,000=600,000$ is means that the object is insured for a total of 600,000 units, which is 150,000 units more than the actual value of the object. With this in mind, it will be necessary to determine the insurance liability of each insurance company.

From here,

$$
\begin{aligned}
C_{b 1} & =\frac{100000}{600000} * 450000=75000 ; \\
C_{b 2} & =\frac{200000}{600000} * 450000=150000 ; \\
C_{b 3} & =\frac{300000}{600000} * 450000=225000 .
\end{aligned}
$$

So, it can be concluded from this issue that in exchange for the insurer insuring an object worth 450,000 units in companies $S_{1}, S_{2}, S_{3}$, the object was damaged as a result of the insured event, but in fact, only 150,000 units were damaged. The amount of this loss was taken into account in $S_{1}, S_{2}, S_{3}$ insurance companies as income in $S_{1}=25,000, S_{2}=50,000, S_{3}=75,000$, respectively.

\section{Discussions}

According to the results of the analysis of the use of modern computing tools in insurance practice, the following evaluation criteria are currently relevant for the insurance market of Uzbekistan.

1) It is necessary as a tool to determine penetration of insurance premiums in Uzbekistan over the years, the level of coverage in the economy, based on the criteria of the share of insurance premiums in the economy or the share of insurance premiums in GDP. Because despite the fact that the annual growth rate is 600 - 700 billion soums, in fact, its density tends to increase by only $0.25 \%$ $0.45 \%$.

2) The density of accrued insurance premiums is also an up-to-date modern means of calculation, which reflects the share of per capita expenditures for insurance during the year. In our example, the fact that the change in this indicator over the selected years is around 2 - 3 dollars means that measures need to be taken in this area. Because the figure is more than $\$ 120$ in developing countries.

3) Probability theory is characterized by the fact that it makes sure that the expected economic events have a detrimental or beneficial outcome for its participants, and encourages them to take measures such as timely prevention or adequate preparedness for possible economic threats. Creating an economic model of economic events based on the principles of probability theory alone serves to simultaneously positively address the issues of its optimization, maximization and minimization. The issues of transportation, matrixing style, cost minimization and revenue maximization are well known and popular in practice.

4) The fact that the world economy is not moving smoothly, economic events are changing very rapidly in interconnected and unrelated ways to determine the 
mathematical expectation of future economic and financial events, evaluate it, develop its necessary criteria, determine the expected insurance rates for future years. I believe that the calculation will help the insurer to reduce the level of future losses of the insurance portfolio.

\section{Conclusion}

Thus, it is clear from the examples considered that the following accounting systems are offered during the leadership of the insurance market and in the event of a global pandemic:

- It is recommended the calculation of density of insurance premium among the indicators required for management staff and its wide implementation in practice;

- To determine the share of insurance premiums calculated in the insurance market in the economy of the selected country, and the plans to be adopted, to take this into account in the projects;

- It is actual and purposeful in-depth analysis of the density of insurance premiums of regional division of the Republic of Uzbekistan while formation of the insurance portfolio;

- It is real problem of assessment of the main types of insurance and its real situation, taking full advantage of the existing opportunities of the theory of probabilities, and based on the reformation of insurance tariff coefficients, continuous risk assessment;

- It is recommended to determine the predictions of insurance premiums which is calculated and accumulated for future activities based on the laws of the regression equation and probability theory;

- I think it is necessary to pay special attention to the reformation of tariffs, conducting insurance analysis that is not harmful to both parties.

\section{Acknowledgements}

I would like to express my deep gratitude to Professor Abdushukurov A. A. and Professor Nasritdinov G., my research supervisors, for their patient guidance, enthusiastic encouragement and useful critiques of this research work. I would also like to thank the specialists of the Departments of Mathematical analysis and Theory of Probability at the National University of Uzbekistan named after MirzoUlug' bekin keeping my progress on schedule and the Academy of Public Administration under the President of the Republic of the Uzbekistan for their organizing me practical internship at the "Uzbekinvest" Export-Import Insurance Company, "Uzagrosug'urta" joint-stock company and Insurance Market Development Agencies under the Ministry of Finance of the Republic of Uzbekistan. My grateful thanks are also extended to specialists of Institute of forecasting and macroeconomic research for their help in doing the methodological data analysis.

I would also like to extend my thanks to the technicians of the National Li- 
brary of Uzbekistan named after Alisher Navoiy for their help in offering me the resources in running the program.

Finally, I wish to thank my parents and all members of my family for their support and encouragement throughout my study on this article.

\section{Conflicts of Interest}

The author declares no conflicts of interest regarding the publication of this paper.

\section{References}

Global Insurance Trends Analysis 2018: Pursuit of Growth Amid Cautious Optimism.

Hisobotlar (2021). https://www.mf.uz/uz/otchety

Insurance Indicators. https://stats.oecd.org/Index.aspx? DatasetCode=INSIND

Lindholm, M., \& Verrall, R. (2020). Regression Based Reserving Models and Partial Information. Insurance: Mathematics and Economics, 94, 109-124.

https://doi.org/10.1016/j.insmatheco.2020.07.001

O`Zbekiston Respublikasi Davlat Statistika Qo`Mitasi. https://stat.uz/uz (Created and Analysed by the Author).

Silvestrov, D., \& Martin-Löf, A. (2014). Modern Problems in Insurance Mathematics. International Cramér Symposium on Insurance Mathematics (ICSIM). Springer International Publishing, Berlin.

Swiss Resigma (2020). Data-Driven Insurance: Ready for the Next Frontier? https://www.insuranceprofessionalslatam.com/data-driven-insurance-disrupting-inlip/ 